MEDIKA ALKHAIRAAT : JURNAL PENELITIAN KEDOKTERAN DAN KESEHATAN 1(1): 30-33

e-ISSN: 2656-7822

\title{
GAMBARAN KADAR ELEKTROLIT DARAH PADA PENDERITA STROKE HEMORAGIK DENGAN KESADARAN MENURUN YANG DI RAWAT DI BAGIAN NEUROLOGI RSU ANUTAPURA PALU TAHUN 2017
}

\author{
Yustiadi Kasuba ${ }^{1}$, Ruslan Ramlan Ramli ${ }^{*}$, Nasrun ${ }^{1}$ \\ ${ }^{1}$ Program Studi Pendidikan Dokter, Fakultas Kedokteran Universitas Alkhairat, Jl. Diponegoro No. 39 Palu \\ 94221, Sulawesi Tengah, Indonesia \\ *Corresponding author: Telp: +6282225257575 email: ramlanruslan@gmail.com
}

\begin{abstract}
ABSTRAK
Stroke hemoragik merupakan penyebab utama kecatatan dan gangguan fungsional yang dapat berdampak pada sosial ekonomi bahkan bisa menyebabkan kematian. Untuk mengurangi angka morbiditas dan mortalitas Stroke hemoragik perlu diketahui Kadar elektrolit pada penderita stroke hemoragik dengan kesadaran menurun. Sehingga dapat mengontrol kadar elektrolit darah agar angka kematian bisa diturunkan. Penelitian ini bertujuan untuk mengetahui gambaran kadar elektrolit darah pada pasien stroke hemoragik dengan kesadaran menurun yang di rawat di Bagian Neurologi RSU Anutapura Palu tahun 2017. Penelitian ini memakai metode deskriptif dengan pendekatan cross sectional. Hasil penelitian yaitu (1) kadar elektrolit natrium pada penderita stroke dengan kesadaran menurun sebagian besar memiliki kadar natrium dalam batas normal 37 orang $(56,9 \%)$ dan sebagian di dapatkan kadar natrium menurun 28 orang $(43,1 \%)$. (2) kadar elektrolit kalium pada penderita stroke hemoragik dengan kesadaran menurun sebagian besar memiliki kadar kalium menurun 35 orang (53,8\%), sebagian di dapatkan kadar kalium dalam batas normal 26 orang (40,0\%) dan kadar kalium yang meningkat 4 orang $(6,2 \%)$. (3) kadar elektrolit clorida pada penderita stroke hemoragik dengan kesadaran menurun sebagian besar memiliki kadar clorida menurun 34 orang (52,3\%), sebagian di dapatkan kadar kalium dalam batas normal 31 orang (47,7\%). Simpulan penelitian yakni kadar elektrolit pada penderita stroke hemoragik dengan kesadaran menurun yang di rawat di bagian neurologi RSU Anutapura palu, bahwa sebagian besar memiliki kadar natrium dalam batas normal (Normonatremi), kadar kalium lebih banyak di dapatkan Hipokalemia, dan sebagian besar kadar clorida di dapatkan hipokloridemia.
\end{abstract}

Kata Kunci : Stroke hemoragik, kadar elektrolit, kesadaran menurun.

\section{ABSTRACT}

Hemorrhagic stroke is a major cause of disorder and functional disorders that can have an impact on socioeconomic conditions and can even cause death. To reduce morbidity and mortality Hemorrhagic stroke needs to be known Electrolyte levels in patients with hemorrhagic stroke with decreased consciousness. So that it can control blood electrolyte levels so that the death rate can be reduced. This study aims to describe the blood electrolyte level in patients with decreased awareness of hemorrhagic stroke treated in the Neurology Section of Anutapura General Hospital in 2017. This study used a descriptive method with a cross sectional approach. The results of the study are (1) sodium electrolyte levels in stroke sufferers with decreased consciousness, most of which have normal levels of sodium in 37 people (56.9\%) and some get sodium levels decreased by 28 people (43.1\%). (2) the potassium electrolyte level in patients with hemorrhagic stroke with a decreased consciousness most have potassium levels decreased by 35 people (53.8\%), some get potassium levels within the normal limit of 26 people (40.0\%) and potassium levels increase 4 people (6.2\%). (3) the electrolyte level of chloride in patients with hemorrhagic stroke with consciousness decreases, most of them have chloride levels decreased by 34 people (52.3\%), some of them get potassium levels within the normal limit of 31 people (47.7\%). The conclusions of the study were electrolyte levels in patients with decreased awareness of hemorrhagic stroke treated in the neurology department of Anutapura Palu General Hospital, that most had normal levels of sodium (Normonatremi). hypochloridemia.

Keywords: Hemorrhagic stroke, electrolyte levels, decreased consciousness. 


\section{PENDAHULUAN}

Stroke hemoragik adalah kerusakan neurologi akut yang terjadi akibat perdarahan intracerebral maupun subarachnoid.yang di sebapkan pecahnya pembuluh darah di dalam atau pada permukaan otak, stroke hemoragik terjadi paling sering dari pecahnya aneurisma atau pembuluh darah yang abnormal terbentuk ${ }^{1}$.

Menurut WHO (2015), stroke hemoragik menjadi penyebab kematian dari 5,7 juta jiwa diseluruh dunia dan diperkirakan meningkat menjadi 6,5 juta penderita pada tahun 2015 dan 7,8 juta penderita pada tahun 2013.Dan di Indonesia sendiri angaka kejadian tiap tahunnya terserang stroke dengan insiden $12,1 \%$ di tahun 2013 (Riskesdas2013). Sedangkan di kota Palu sendiri angka kejadian stroke hemoragik yang di rawat di rumah sakit anutapura Palu sebanyak 45 jiwa pada tahun 2013. Pada tahun 2014 yaitu 37 jiwa. Kemudian pada tahun 2015 sebanyak 139 jiwa dan pada tahun 2016 meningkat menjadi 189 jiwa.

Penyebab stroke hemoragi antara lain: hipertensi, pecahnya aneurisma, malformasi arteri venosa. Biasanya kejadiannya saat melakukan aktivitas atau saat aktif, namun bisa juga terjadi saat istirahat. Kesadaran pasien umumnya menurun .Perdarahan tersebut menyebabkan gangguan serabut saraf otak melalui penekanan struktur otak dan juga oleh hematom yang menyebabkan iskemia pada jaringan sekitarnya. Peningkatan tekanan intrakranial pada gilirannya akan menimbulkan herniasi jaringan otak dan menekan batang otak sehingga terjadi penurunan kesadaran.

\section{METODOLOGI}

Desain penelitian yang digunakan adalah penelitian yang bersifat Deskriptif observasional dengan pendekatan Cross sectional. Dimana pengambilan data dilakukan hanya satu kali pada satu saat. Penelitian ini di mulai 19 desember 2017 sampai 13 april 2018, di Bagian Neurologi RSU Anutapura Palu.

Subyek Penelitian adalah semua pasien stroke henorhagik yang mengalami kesadara menurun yang telah di periksa kadar elektroit dan CT-Scan.
Pengambilan sampel pada penelitian ini adalah consecutive sampling yang merupakan salah satu cara dari nonprobability sampling. Dengan cara consecutive, peneliti mengambil semua subjek stroke hemoragik yang mengalami kesadaran menurun yang memenuhi kriteria, sampai besar sampel terpenuhi.

Rencana analisis data yang digunakan yaitu deskriptif kategorik. Untuk perhitungan statistik menggunakan aplikasi SPSS for windows 17.0 sehingga hasilnya bisa didapat berupa frekuensi dan presentasi (proporsi) yang disajikan dalam bentuk table, grafik, diagram batang dan diagram pie.

\section{HASIL DAN PEMBAHASAN}

HASIL

Penelitian ini dilakukan di Bagian Neurologi RSU Anutapura Palu sejak bulan Desember 2017 sampai April 2018 terhadap pasien yang menderita stroke hemoragik yang di rawat di Bagian Neurologi memenuhi kriteria sampel sebanyak 65. Pengumpulan data pada penelitian ini dilakukan dengan pengambilan data responden dengan menggunakan case report. Adapun data yang diperoleh terdiri dari gambaran Kadar elektrolit Natrium, kalium, Clorida pada penderita stroke hemoragik. Hasil analisa statistik ditampilkan dengan sistematik sebagai berikut:

\section{Gambaran Kadar Elektrolit Natrium serum pada} penderita Stroke Hemoragik.

Gambaran kadar elektrolit natrium serum padaa penderita stroke hemoragik di lakukan kategorisasi kadarelektrolit natrium serum dan selanjutnya di lakukan analisis distribusi (Table 1).

Table 1. Distribusi kategori kadar natrium pada penderita stroke hemoragik dengan kesadaran menurun. RSU Anutapura Palu.

\begin{tabular}{|lccc|}
\hline Kadar Natrium serum & $\mathrm{N}$ & $\%$ & $\mathrm{CP}$ \\
\hline 1. Normal & 37 & 56,9 & 56,9 \\
2. Tinggi & 0 & 0,0 & 0,0 \\
3. Menurun & 28 & 43,1 & 100,0 \\
\hline Total & 65 & 100,0 & \\
\hline
\end{tabular}


Tabel 1 menunjukan bahwa masih di temukan sebagian $(56,9 \%)$ penderita stroke hemoragik mempunyai kadar natrium serum masih dalam batas normal tetapi hampir sebagian memiliki kadar yang rendah $(43,1 \%)$ tidak di temukan kadar natrium yang tinggi. Ini menunjukan bahwa pada penderita stroke hemoragik kadar natrium serum enderung mengalami penurunan.

Gambaran Kadar Elektrolit darah (Kalium) pada penderita Stroke Hemoragik.

Gambaran kadar elektrolit kalium serum pada penderita stroke hemoragik di lakukan kategorisasi kadar elektrolit kalium serum dan selanjutnya di lakukan analisis distribusi (Table 2).

Table 2. Distribusi kadar kalium pada penderita stroke hemoragik dengan kesadaran menurun. RSU Anutapura palu.

\begin{tabular}{|lccc|}
\hline Kadar Natrium serum & $\mathrm{N}$ & $\%$ & $\mathrm{CP}$ \\
\hline 1. Normal & 26 & 40,0 & 40,0 \\
2. Tinggi & 4 & 6,2 & 46,2 \\
3. Menurun & 35 & 53,8 & 100,0 \\
\hline Total & 65 & 100,0 & \\
\hline
\end{tabular}

\section{Uji Deskriptif}

Tabel 2 menunjukan bahwa masih di temukan sebagian $(40,0 \%)$ penderita stroke hemoragik dengan kesadaran menerun mempunyai kadar kalium serum masih dalam batas normal tetapi hampir sebagian memiliki kadar yang rendah $(53,8 \%)$ dan di temukan kadar kalium yang tinggi $(6,2)$. Ini menunjukan bahwa pada penderita stroke hemoragik kadar natrium serum cenderung mengalami penurunan.

Gambaran Kadar Elektrolit darah (Clorida) pada penderita Stroke Hemoragik

Gambaran kadar elektrolit kalium serum pada penderita stroke hemoragik di lakukan kategorisasi kadar elektrolit kalium serum dan selanjutnya di lakukan analisis distribusi (Table 3).
Table 3. Distribusi kadar Clorida pada penderita stroke hemoragik dengan kesadaran menurun RSU Anutapura Palu.

\begin{tabular}{|lccc|}
\hline Kadar Natrium serum & $\mathrm{N}$ & $\%$ & $\mathrm{CP}$ \\
\hline 1. Normal & 31 & 47,7 & 47,7 \\
2. Tinggi & 0 & 0,0 & 0,0 \\
3. Menurun & 34 & 52,3 & 100,0 \\
\hline Total & 65 & 100,0 & \\
\hline
\end{tabular}

\section{Uji Deskriptif}

Tabel 3 menunjukan bahwa masih di temukan sebagian $(47,7 \%)$ penderita stroke hemoragik dengan kesadaran menerun mempunyai kadar clorida serum masih dalam batas normal tetapi hampir sebagian memiliki kadar yang rendah $(52,3 \%)$ tidak di temukan kadar kalium yang tinggi. Ini menunjukan bahwa pada penderita stroke hemoragik kadar natrium serum cenderung mengalami penurunan.

\section{PEMBAHASAN}

Gambaran Kadar Elektrolit Natrium pada penderita Stroke Hemoragik dengan kesadaran menurun

Distribusi kadar elektrolit natrium pada penderita stroke dengan kesadaran menurun sebagian besar memiliki kadar natrium dalam batas normal 37 orang $(56,9 \%)$ dan sebagian di dapatkan kadar natrium menurun 28 orang $(43,1 \%)$. Penilitian ini sejalan dengan penelitian yang dilakukan oleh (Mieke, 2013) di RSUP Prof. Dr.R.D ${ }^{3}$. Kandou Manado yang menyatakan bahwa se bagian besar pasien stroke hemoragik memiliki kadar natrium dalam batas normal (70\%), hiponatremia didapatkan $28 \%$ sedangkan hipernatrium 2\%. Penilitian ini juga sejalan dengan penelitian (Alfianto at al, 2016) yaitu status kadar natrium darah pada pasien stroke hemoragik antara lain hiponatremia sebanyak 5 pasien $(15,2 \%)$, normonatremia sebanyak 25 pasien $(75,8 \%)$ dan hipernatremia sebanyak 3 pasien $(9,1$ $\%)^{4}$. 
Gambaran Kadar Elektrolit darah (Kalium) pada pend erita Stroke Hemoragik dengan kesadaran menurun

Distribusi kadar elektrolit kalium pada penderita stroke hemoragik dengan kesadaran menurun sebagian besar memiliki kadar kalium menurun 35 orang $(53,8 \%)$, sebagian di dapatkan kadar kalium dalam batas normal 26 orang $(40,0 \%)$ dan kadar kalium yang meningkat 4 orang $(6,2 \%)$. Penilitian ini sejalan dengan penelitian yang dilakukan oleh (Shinta at al, 2011) yang menyatakan bahwa status kadar kalium darah pada pasien stroke hemoragik antara lain hipokalemia sebanyak $(57,2 \%)$, normokalemia sebanyak $(83,8 \%)$ dan hiperkalemia sebanyak $(9,1 \%)$.

Secara teori dapat di jelaskan bahwa Orang tua yang hanya makan roti panggang dan teh, peminum alkohol yang berat sehingga jarang makan dan tidak makan dengan baik, atau pada pasien sakit berat seperti stroke hemoragik dengan kesadaran menurun yang tidak dapat makan dan minum dengan baik melalui mulut atau disertai oleh masalah lain misalnya pada pemberian diuretik atau pemberian diet rendah kalori pada program menurunkan berat badan dapat menyebabkan hipokalemia.

\section{Gambaran Kadar Elektrolit darah (Clorida) pada penderita Stroke Hemoragik dengan kesadaran menurun}

Distribusi kadar elektrolit clorida pada penderita stroke hemoragik dengan kesadaran menurun sebagian besar memiliki kadar clorida menurun 34 orang $(52,3 \%)$, sebagian di dapatkan kadar kalium dalam batas normal 31 orang $(47,7 \%)$. Penilitian ini juga sejalan dengan penelitian yang dilakukan oleh (Patricia at al, 2011) yang menyatakan Pasien stroke hemoragik yang memiliki kadar klorida rendah (hipokloridemia) sebanyak 8 pasien $(10,7 \%)$ dan hiperkloridemia sebanyak 6 pasien (8\%). Hal ini dapat di jelaskan bahwa Hipokloridemia terjadi jika pengeluaran klorida melebihi pemasukan. Penyebab hipoklorinemia umumnya sama dengan hiponatremia, tetapi pada alkalosis metabolik dengan hipoklorinemia, defisit klorida tidak disertai defisit natrium.

\section{DAFTAR PUSTAKA}

1. Scott M.G., LeGrys, V.A. and Klutts J, 'Electrochemistry and Chemical Sensors and Electrolytes and Blood Gases" In: Tietz Text Book of Clinical Chemistry and Molecular Diagnostics, 4th Ed. Vol.1, Elsevier Saunders Inc., Philadelphia, 2006, pp. 93-1014.

2. Depkes RI. (2009) Profil Kesehatan Indonesia 2008. Dalam http://www.depkes.go.id di akses 16 juni 2015.

3. Mieke A. H. N. Kembuan, Gambaran Gangguan kadar natrium serum pada pasien stroke di RSUP. Prof. DR. R.D. Kandou manado, Jurnal Biomedik (JBM), Volume 5, Nomor 2, Juli 2013, hlm. 80-86.

4. Alifianto P. Parakkasi1, Hexanto M. Hardian.(2016). Hubungan kadar natrium serum saat masuk dengan keluar motorik pasien stroke hemoragik. JKD, Vol. 5, No. 4, Oktober 2016 : $337-346$. 